\title{
Resiliensforståelser $\mathbf{i}$ skoleverdenen
}

\author{
Jeppe Kiel Christensen ${ }^{\star 1}$, Peter Berliner ${ }^{2}$ og Ida Skytte Jakobsen ${ }^{3}$ \\ ${ }^{1}$ Danmarks institut for Pcedagogik og Uddannelse, Aarhus Universitet, ${ }^{2}$ Institut for Samfund, \\ Økonomi \& Fournalistik, Ilisimatusarfik - Gronlands Universitet, ${ }^{3}$ Center for anvendt \\ velfardsforskning UCL Erhvervsakademi og Professionshøjskole, Danmark
}

\section{RESYMÉ}

Artiklen undersøger gennem et systematisk review af litteratur, hvordan et engelsk begreb, resilience, fortolkes og præsenteres i relation til den danske skole. Fokus ligger således på, hvordan resiliensbegrebet bevager sig $i$ tekstformidlingen til dansk skolepraksis. Artiklen præsenterer en kort beskrivelse af resiliensbegrebet i psykologisk optik og argumenterer for resiliens som et vagt begreb. Hvad vil det for eksempel sige, at et barn har klaret sig godt i skolen? I den tematiske analyse af udvalgt litteratur $(\mathrm{n}=23)$, identificeres tre bevægelser i relation til resiliensbegrebet: Resiliens, robusthed og livsduelighed. Et gennemgående træk i de identificerede bevægelser er, at flere forfattere anvender en komponentteori, hvor der optræder en dualistisk orienteret opfattelse af komponenter, altså et samspil mellem noget indre og noget ydre. Kompleksiteten i resiliensbegrebet og de mange forskellige bud på afgrænsning (vaghed) kan betyde, at resiliens, robusthed og livsduelighed bliver blandet sammen, når resiliens diskuteres i forhold til børn og unge i Danmark. Artiklen afsluttes med perspektiver på nødvendigheden af at skærpe begrebet i en dansk skolekontekst, da resiliens rummer stor kompleksitet og vaghed.

Nøgleord: Resiliens; Robusthed; Livsduelighed; Skole; Fællesskab

\begin{abstract}
Resilience views in the school world

Through a systematic literature review, this paper investigates how the English concept resilience is translated and presented in relation to Danish schools (In Danish: resiliens). The paper presents a short description of resilience in a psychological perspective and argues that resilience should be viewed as a vague concept. For example, what does it mean when we say a child did well in school? In a thematic analysis of selected literature $(n=23)$ we identify three flows in relation to the concept of resiliens: Resilience (resiliens), robustness (robusthed) and vitality (livsduelighed). A recurring feature in the identified flows is that several authors use a component theory - a dualistic oriented perception of components, meaning an interaction between something internal and something external. The complexity in the concept of resilience, together with the many borderline cases (vagueness), means that resilience, robustness and vitality often are mixed together, when resilience is debated in relation to children and youths in Denmark. The paper concludes with a perspective
\end{abstract}

\footnotetext{
^Korrespondanse: Jeppe Kiel Christensen, DPU, Aarhus Universitet. Epost: jehc@edu.au.dk (C) 2019 Jeppe Kiel Christensen, Peter Berliner og Ida Skytte Jakobsen. This is an Open Access article distributed under the terms of the Creative Commons Attribution 4.0 International License (https://creativecommons.org/licenses/by-nc/4.0/), allowing third parties to copy and redistribute the material in any medium or format and to remix, transform, and build upon the material for any purpose, even commercially, provided the original work is properly cited and states its license. Citation: Feppe Kiel Christensen, Peter Berliner og Ida Skytte fakobsen. "Resiliensforståelser i skoleverdenen.» Nordisk tidsskrift for pedagogikk og kritikk, Vol. 5, 2019, pp. 311-327. http://dx.doi.org/10.23865/ntpk.v5.1485
} 
on the necessity of sharpening the concept in a Danish school context, as resilience definitions hold great complexity and vagueness, which should be contextualised at a national level.

Keywords: Resilience; Robustness; School; Community

Mottatt: November, 2018; Antatt: Oktober, 2019; Publisert: Desember, 2019

\section{Resiliens i en skolekontekst}

Resilience, eller på nordisk resiliens, handler på et generelt niveau, om at noget, som bliver udsat for et pres eller en belastning, kan finde tilbage eller transformere sig til en form eller ligevægt igen. Vidt forskellige videns- og praksisområder bruger resiliensbegrebet til at fange det fænomen, hvor noget, efter at have været udsat for en belastning, fungerer igen. For eksempel i relation til klima, økonomi, byplanlægning og beredskabsstrategi, hvor begrebet, alt efter kontekst, har forskellige definitioner. Resiliens benyttes også inden for børne- og ungeområdet, herunder nu også skoleområdet, hvor begrebet ligeledes tillægges forskellige betydninger og definitioner. Børn og unge bruger en stor del af deres liv i skolen. Her møder de andre børn, de møder professionelle voksne, og de møder samfundets krav omsat til institutionel praksis. Den trivsel og mentale sundhed, som kan grundlægges gennem skolen, kan og vil ofte have stor betydning for resten af deres liv. Vi har i de senere år set, at resiliensbegrebet er blevet til en del af skolens arbejde med mental sundhed og trivsel i forhold til børn, familier og grupper, der bliver udsat for pres eller belastning. Men hvordan formidles og forstås viden om resiliens i tekster rettet mod den danske skoleverden?

Inden vi præsenterer et muligt svar på dette spørgsmål, opridses kort udviklingen af resiliensbegrebet inden for psykologien, der er denne artikels domæne.

\section{Resiliensbegrebet}

Ordet resiliens stammer fra latin, hvor det er substantivet afledt af verbet resilire, der betyder at springe tilbage (som når en bold rammer en mur og springer tilbage fra den). Ordet er sammensat af re- (tilbage) + salire (at hoppe, at springe). Salire rummer betydningen af en overraskende, hurtig bevægelse. Det betegner også saltning af madvarer, fx kød og fisk, for at gøre dem modstandsdygtige mod forrådnelse og dermed bevare dem spiselige i længere tid. Resiliensbegrebet har en leksikal definition $^{1}$, hvor det i psykologi benyttes som betegnelse for evnen til at komme sig efter sygdom, tab og anden modgang i livet. Begrebet er i en stadig udvikling, idet det ikke mere blot omfatter evnen til at vende tilbage til en tidligere tilstand. Det omfatter også læring og udvikling, der sikrer fortsat funktionsduelighed under ændrede vilkår

${ }^{1}$ Gupta, Anil, "Definitions”, The Stanford Encyclopedia of Philosophy (Fall 2019 Edition), Edward N. Zalta (ed.), URL = <https://plato.stanford.edu/archives/fall2019/entries/definitions/> 
i form af pres eller modgang. Det er et systems evne til forsat tilpasning, forandring og udvikling under ændrede vilkår.

Resiliensbegrebet har eksisteret inden for psykologien i over tres år. Masten beskriver udviklingen af begrebet som en bevægelse gennem fire bølger (Masten, 2001), der startede med en interesse for usårlige børn i første bølge (1960'erne), dernæst forløbsundersøgelser hvor man fik øjnene op for ressourcer omkring barnet i anden bølge (1980'erne). Dette ledte til tredje bølge (1990'erne), hvor interessen ligger på interventioner, altså at skabe betingelser, der understøtter resiliens. I fjerde bølge (2000'erne) ligger fokus på neuropsykologiske forklaringsmodeller og probabilistisk epigenetik $^{2}$ (Masten, 2014; Sommer, 2017). Masten skrev i 2001 en meget citeret artikel indenfor resiliensforskningen, hvori hun beskrev, hvordan de tidligere formuleringer som superbørn fra ghettoen og de usårlige børn bidrog til at placere størstedelen af ansvaret for succes i livet hos børnene selv. I den senere internationale litteratur om resiliens bliver resiliens opfattet både som et samspil mellem individer og kontekst samt som en særlig styrke i et socialøkologisk miljø, som beskrives af blandt andre Leadbeater, Dodgen, \& Solarz (2005) og Ungar (2012). I nyere forskning synes der at være en vis konsensus om, at resiliens kan læres og udvikles gennem nærmiljøer såsom familier og skoler (Lipsitt \& Demick, 2012; Prince-Embury \& Saklofske, 2013; Zautra, Hall, \& Murray, 2010). Her bliver det vigtigt at se på miljøer samt relationer omkring børnene, som kan tilbyde mulige beskyttelsesfaktorer og herigennem understøtte børnenes resiliensprocesser.

Modeller og teorier til at beskrive resiliens indeholder ofte, hvad man kunne betegne som komponentteorier, for at favne samspillet mellem resiliensskabende vilkår hos barnet og i miljøet. Dette gælder både systemiske teorier og socialøkologiske forståelser af resiliens (Ungar, 2012) samt samspilsfokuserede teorier (Hart, Blincow, \& Thomas, 2007). Forskellen er kort sagt, at systemiske teorier ser på helheden som større end summen af delene, og som det der skaber delene (komponenterne), mens samspilsteorier ser på komponenterne og disses indbyrdes samspil.

Resiliensbegrebet har ikke en enkelt klar definition, model eller teori. Dette er sandsynligvis, fordi begrebet rummer en stor kompleksitet, eftersom det sammenfatter en proces med mange aspekter i ét enkelt ord. At klare sig godt igen efter belastning involverer flere indbyrdes forbundne processer og elementer der ikke er adskilte eller har klare grænser mellem sig. Selve processen er toleddet, at klare sig godt og belastning. Begge disse størrelser kan ses som vage, hvilket betyder, at resiliens kan anskues som et vagt begreb. ${ }^{3}$ Et begreb er vagt, når grænsetilfældene ikke er tydelige. Hvad vil det for eksempel sige, at et barn har klaret sig godt $i$ skolen? Er det ved at bestå en eksamen med et højt gennemsnit, eller er det, når en voksen kan se tilbage på sin skoletid som tryg og meningsfuld?

\footnotetext{
${ }^{2}$ Forskning i hvordan miljøoplevelser kan tænde og slukke for gener.

${ }^{3}$ Sorensen, Roy, "Vagueness", The Stanford Encyclopedia of Philosophy (Summer 2018 Edition), Edward N. Zalta (ed.), URL $=<$ https://plato.stanford.edu/archives/sum2018/entries/vagueness/>
} 
Forfatterne foretog omfattende googlesøgninger på resiliens i studiets indledende fase i 2017, og søgningerne bekræftede et uklart billede af resiliensbeskrivelser. Der findes utallige definitioner, tilgange og metoder, som dækker alt fra korrekte referencer til decideret misvisende information. Dermed er der et behov for en systematisk undersøgelse af de bevægelser, et vagt begreb, resiliens, foretager i oversættelsen til den danske folkeskole. Artiklens formål er at undersøge, hvordan resiliensbegrebet bevager sig $i$ tekstformidlingen til dansk skolepraksis. Metoden er et litteraturstudie, der gennemgår dansk litteratur fra 2000 og frem, med fokus på hvordan resiliensbegrebet bliver beskrevet i sammenhæng med den danske folkeskole.

\section{Metode}

For at svare på hvordan resiliens formidles og forstås i tekster rettet mod den danske skoleverden, er der foretaget en systematisk litteratursøgning. Fokus er på skolen, og derfor er mange udgivelser om resiliens hos børn og unge ekskluderet, hvis de ikke har fokus på skolen. Litteraturstudiet blev gennemført systematisk i udvalgte databaser og inden for et afgrænset område. Studiet bestod af fem faser, hvoraf der var iterative processer (feedback loops) forbundet med både fase 2 og 4. Sideløbende blev der foretaget håndsøgning, hvor gennemgangen bestod af en tostrenget søgestrategi.

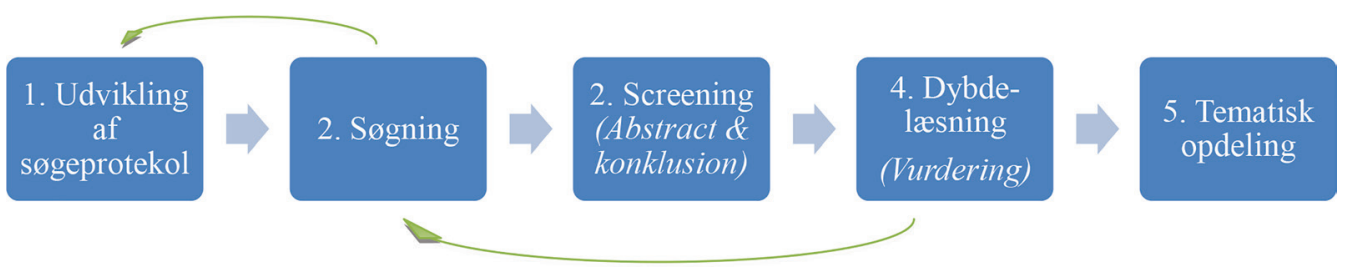

Figur 1. Review fremgangsmåde.

Udviklingen af søgeprotokollen tog udgangspunkt i to nøgleværker indenfor international resiliensforskning (Masten, 2014; Ungar, 2012). Der blev ligeledes foretaget en initial søgning i Thesaurus samt foretaget quick and dirty søgninger på et bredt udvalg af databaser, herunder Google og Google Scholar. Der blev også foretaget citationssøgninger på den udvalgte primærlitteratur. Dette ledte til to søgestrenge på henholdsvis dansk og engelsk, benyttet i Bibliotek.dk, PsycINFO, ERIC og SCOPUS:

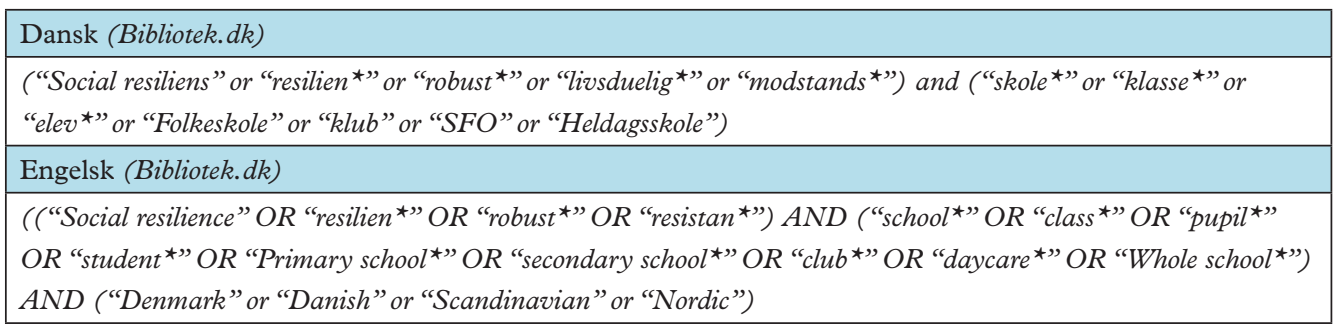


Søgningen blev foretaget 20.04.2018 med følgende afgrænsning:

\begin{tabular}{|l|l|}
\hline Sprog & Dansk, svensk, norsk og engelsk \\
\hline Publikationer & Journaler, magasiner, tidsskrifter, policy, lærebøger, aviser og ikke-fiktion. \\
\hline Tid & $2000-2018$ \\
\hline Andet & Grundskole, Danmark \\
\hline
\end{tabular}

Som supplement til den systematiske søgning indgik en håndsøgning baseret på løbende oplæg, observationer og interviews på skoler, referencer fra netværk, udviklingsprojekter såsom Stærke Sammen (Red Barnet) og Resilient Vejle. Ligeledes blev der søgt ved udvalgte institutioner såsom NUBU, DPU, VIA, SFI, DCUM og Undervisningsministeriet.

\section{Resultater}

I den udvalgte litteratur ( $\mathrm{n}=98$ ) tales der om resiliens som en for-danskning, fornorknning og for-svenskning af resilience. Dermed er første punkt i resultaterne, at der i Norge, Sverige og Danmark tales om resiliens på tværs af de tre lande. De inkluderede tekster $(n=23)$ fordeler sig med primært fokus på resiliens og/eller robusthed.

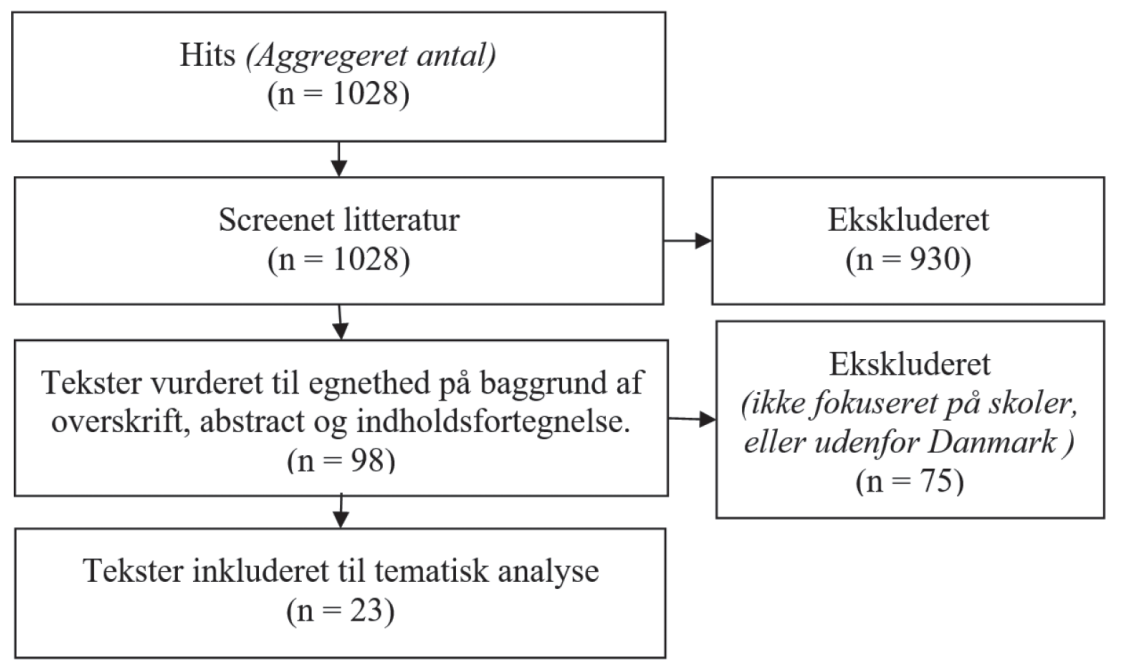

Livsduelighed og modstandskraft blev medtaget i søgestrengen, da de ofte figurerede i tekster under udarbejdelsen af søgeprotokollen. Det viste sig dog ved dybdelæsning, at livsduelighed og modstandskraft bliver beskrevet som underordnede begreber eller udspringer af resiliens- og robusthedsforståelser. Livsduelighed er i ét tilfælde en direkte oversættelse af resilience (Cefai, 2008, 2009). Modstandskraft figurerer ikke som overordnet begreb i nogen af teksterne. Derfor kan det konkluderes, at resiliens, robusthed og livsduelighed er de tre overordnede begreber $\mathrm{i}$ tekster om resiliens $\mathrm{i}$ relation til den danske skole. Begreberne overlapper i teksterne og væver sig ind i hinanden, hvilket giver et billede uden klare begrebsdefinitioner. Dog fremgår det, 
at resiliens og robusthed ofte sidestilles, men at resiliens også i visse tilfælde ses som overbegreb for robusthed.

\section{Tematisk analyse}

Teksterne $(n=23)$ beskriver alle arbejdet med resiliens i relation til skolen. Teksterne er beskrivelser fra forskellige faggrupper med relation til skolen. Derfor afspejler teksterne også forskelligt fokus, henholdsvis på individuel risiko i specifikke grupper af børn eller mere almene risiko- og beskyttelsesfaktorer i kontekster relateret til skolen. Teksterne repræsenterer derfor brugen/beskrivelser/definitioner af begrebet resiliens i relation til skolen, og følgende afsnit er ikke en vurdering af interventioner eller deres effektivitet. De udvalgte publikationer $(n=23)$ er med deres hovedkarakterisering og fokus præsenteret som overblik i tabel 1.

Tabel 1: Hovedkarakterisering og fokus

\begin{tabular}{|c|c|c|}
\hline Forfatter & Hovedkarakterisering & Fokus \\
\hline \multicolumn{3}{|c|}{ Resiliens } \\
\hline $\begin{array}{l}\text { Nielsen, } 2004 \\
\text { (Bog) }\end{array}$ & $\begin{array}{l}\text { Resiliens i kombination af evne } \\
\text { og støtten i netværket. Barnet får } \\
\text { mulighed for at udvikle evner til at } \\
\text { opsøge støtte i netværket. } \\
\text { Bruger det engelske ord resilience. }\end{array}$ & $\begin{array}{l}\text { Ikke kun individuelle egenskaber understøtter } \\
\text { resiliensprocesser, men også styrkende sociale } \\
\text { relationer i form af tilknytning, støtte og } \\
\text { accept samt opbygning af nye alternative } \\
\text { narrativer præget af sammenhæng. }\end{array}$ \\
\hline $\begin{array}{l}\text { Sørensen, } 2008 \\
\text { (Bog) }\end{array}$ & $\begin{array}{l}\text { Resiliens er indlejret både og uden for } \\
\text { barnet, ikke blot biologisk robusthed/ } \\
\text { medfødte potentialer. } \\
\text { Miljøet spiller en aktiv rolle i } \\
\text { udfoldelsen af resiliens. }\end{array}$ & $\begin{array}{l}\text { Resiliensfremmende faktorer i og omkring } \\
\text { barnet kan understøtte positiv udvikling og } \\
\text { imødekomme problemstillinger. } \\
\text { Mønsterbrydning: Omstændighederne, der } \\
\text { gør, at ikke alle rammes af social arv. } \\
\text { Børn dobbeltsocialiseres i Danmark, } \\
\text { hvilket gør lærere og pædagoger til vitale } \\
\text { forebyggende personer og skolen til et } \\
\text { resiliensunderstøttende miljø. }\end{array}$ \\
\hline $\begin{array}{l}\text { Sejer Nielsen, } \\
2014 \\
\text { (Artikel) }\end{array}$ & $\begin{array}{l}\text { Menneskets proces, med et blik for } \\
\text { resiliens som kontekstuel og dermed } \\
\text { knyttet til en institutionel ramme. }\end{array}$ & $\begin{array}{l}\text { Skolen og det at få mulighed for at påbegynde } \\
\text { en resiliensproces i den institutionelle ramme } \\
\text { som en vigtig faktor i forebyggelse i en } \\
\text { risikofyldt tilværelse. }\end{array}$ \\
\hline $\begin{array}{l}\text { Rasmussen, } 2014 \\
\text { (Artikel) }\end{array}$ & $\begin{array}{l}\text { Resiliens udvikler sig i samspillet } \\
\text { mellem individuelle medfødte } \\
\text { egenskaber og omgivelserne. }\end{array}$ & $\begin{array}{l}\text { Beskyttelsesbegrebet kan ikke ses uafhængigt } \\
\text { af sammenhængen. Beskyttelse i én } \\
\text { sammenhæng kan være en risiko i en anden. }\end{array}$ \\
\hline $\begin{array}{l}\text { Jakobsen, 2014, } 2017 \\
\text { (Bog-kapitler) }\end{array}$ & $\begin{array}{l}\text { Resiliens defineres som en proces, der } \\
\text { er et resultat af dynamiske samspil } \\
\text { mellem barnet og dets omgivelser. }\end{array}$ & $\begin{array}{l}\text { Ser resiliens som paraply-begreb for et relativt } \\
\text { komplekst fænomen. } \\
\text { Proces hvor nogen påvirkes af noget og vender } \\
\text { tilbage til en ligevægt igen eller klarer dette } \\
\text { noget bedre end forventet. }\end{array}$ \\
\hline
\end{tabular}




\begin{tabular}{|c|c|c|}
\hline Forfatter & Hovedkarakterisering & Fokus \\
\hline $\begin{array}{l}\text { Spicker, } 2016 \\
\text { (Artikel) }\end{array}$ & $\begin{array}{l}\text { Resiliens er indlejret i personen og } \\
\text { dennes forholden sig til verden. Det } \\
\text { handler ikke om miljøpåvirkninger, } \\
\text { snarere om hvordan individet } \\
\text { håndterer disse påvirkninger. }\end{array}$ & $\begin{array}{l}\text { Resiliens Trænings Program med udpræget } \\
\text { individualiserende afsæt i forståelsen af } \\
\text { resiliens. } \\
\text { Sammenhæng mellem selvregulering og gode } \\
\text { relationer. }\end{array}$ \\
\hline $\begin{array}{l}\text { Leoni, } 2016 \\
\text { (Materiale) } \\
\text { Ladegaard, } 2016 \\
\text { (Rapport) }\end{array}$ & $\begin{array}{l}\text { Resiliens opfattes som samspil } \\
\text { mellem den enkelte og fællesskaber, } \\
\text { samt hvordan de gensidigt styrker } \\
\text { hinanden. }\end{array}$ & $\begin{array}{l}\text { Fællesskabet som en betydningsfuld del af } \\
\text { resiliens. } \\
\text { Styrke og det stærke, trygge fællesskab. } \\
\text { Den indre evne er del af } \\
\text { komponentforståelsen. }\end{array}$ \\
\hline $\begin{array}{l}\text { Dalsgaard, } \\
\text { Elkrog Hansen, \& } \\
\text { Skovgaard, } 2016 \\
\text { (Rapport) }\end{array}$ & $\begin{array}{l}\text { Resiliens og robusthed anvendes } \\
\text { synonymt. } \\
\text { Robusthed mangler et element af } \\
\text { elasticitet, som rummes af resiliens. }\end{array}$ & $\begin{array}{l}\text { Resiliensfremme i skolen og lærernes } \\
\text { handlinger. Benytter Hendersons resilienshjul, } \\
\text { med seks resiliensunderstøttende områder i } \\
\text { skolen (Udfoldes i næste afsnit). }\end{array}$ \\
\hline $\begin{array}{l}\text { Linder (2016a, } \\
\text { 2016b) (Kapitel og } \\
\text { bog) }\end{array}$ & $\begin{array}{l}\text { Knytter resiliensbegrebet sammen } \\
\text { med et begreb om livsduelighed, } \\
\text { der omfatter handlingstillid, håb og } \\
\text { optimisme. }\end{array}$ & $\begin{array}{l}\text { Resiliens dækker i livsduelighedsperspektivet } \\
\text { på-trods-af modgang. Resiliens mangler dog } \\
\text { det mere positive twist, som livsduelighed } \\
\text { rummer. }\end{array}$ \\
\hline $\begin{array}{l}\text { Roffey, } 2017 \\
\text { (Artikel) }\end{array}$ & $\begin{array}{l}\text { Resiliens skabes i et støttende miljø } \\
\text { og af hverdagens magikere, der omgiver } \\
\text { børnene. }\end{array}$ & $\begin{array}{l}\text { Udforskning af de faktorer som bidrager til } \\
\text { venskab, inklusion og støtte blandt børnene. } \\
\text { Læringsmiljøets sociale aspekter. } \\
\text { Hverdagens magikere: fagprofessionelle og } \\
\text { private relationer i barnets liv. }\end{array}$ \\
\hline $\begin{array}{l}\text { Belling \& Frandsen, } \\
2017 \text { (Bog) }\end{array}$ & $\begin{array}{l}\text { Brede begreber uden klare } \\
\text { definitioner. }\end{array}$ & Resiliens som tilpasning til forandringer. \\
\hline $\begin{array}{l}\text { Månsson, } 2017 \\
\text { (Artikel) }\end{array}$ & $\begin{array}{l}\text { Resiliens som et socialt fænomen, der } \\
\text { kan forandres over tid. Der lægges } \\
\text { vægt på socialøkologiske begreber } \\
\text { som forhandling og navigation (Ungar, } \\
2012 \text { ). }\end{array}$ & $\begin{array}{l}\text { Social resiliens som en udviklingsproces. } \\
\text { Afhængig af samspillet mellem de sociale } \\
\text { relationer og den enkelte. }\end{array}$ \\
\hline
\end{tabular}

\begin{tabular}{|c|c|c|}
\hline \multicolumn{3}{|c|}{$\begin{array}{l}\text { Robusthed } \\
\end{array}$} \\
\hline $\begin{array}{l}\text { Hansen, } 2006 \\
\text { (Bog-kapitel) }\end{array}$ & $\begin{array}{l}\text { Robusthed som den enkeltes styrke. } \\
\text { Begrebet suppleres med resiliens, } \\
\text { der forstås som: Ukuelighed, } \\
\text { livsmod, livskraft, spændstighed og } \\
\text { elasticitet. }\end{array}$ & $\begin{array}{l}\text { En række begreber suppleres med hinanden } \\
\text { i beskrivelsen af overlevere. Fokus ligger på } \\
\text { beskrivelser af den individuelle komponent. }\end{array}$ \\
\hline $\begin{array}{l}\text { Bak, } 2016 \\
\text { (Bog-kapitel) }\end{array}$ & $\begin{array}{l}\text { Robusthed har individuelle medfødte } \\
\text { grænser. } \\
\text { Sætter lighedstegn mellem resiliens og } \\
\text { robusthed. }\end{array}$ & $\begin{array}{l}\text { Den individuelle robusthed påvirkes af } \\
\text { kontekster gennem livet. Repræsenterer et } \\
\text { individualiseret syn på menneskers styrke. }\end{array}$ \\
\hline $\begin{array}{l}\text { Bak \& Lima, } 2017 \\
\text { (Bog) }\end{array}$ & $\begin{array}{l}\text { Skriver direkte at der ingen } \\
\text { definitionsmæssig forskel er på } \\
\text { resiliens og robusthed. }\end{array}$ & Benytter to begreber om det samme fænomen. \\
\hline
\end{tabular}




\begin{tabular}{|c|c|c|}
\hline Forfatter & Hovedkarakterisering & Fokus \\
\hline $\begin{array}{l}\text { Schultz Jørgensen, } \\
2017 \\
(\text { Bog) }\end{array}$ & $\begin{array}{l}\text { Skelner mellem robusthed som adferd } \\
\text { og robusthed som egenskab. } \\
\text { I definitionen af resiliens benyttes } \\
\text { modstandskraft, robusthed og } \\
\text { resiliens i samme sætning. }\end{array}$ & $\begin{array}{l}\text { Robusthed defineret som individuelt og } \\
\text { miliømæssigt på samme tid. }\end{array}$ \\
\hline \multicolumn{3}{|c|}{ Livsduelighed } \\
\hline $\begin{array}{l}\text { Cefai, } 2009 \\
\text { (Bog) }\end{array}$ & $\begin{array}{l}\text { (Uddannelsesmæssig) Resiliens } \\
\text { er socialemotionel kompetence } \\
\text { og engagement i klassen, som } \\
\text { understøtter sund udvikling i alle } \\
\text { børn. }\end{array}$ & $\begin{array}{l}\text { Dansk oversætter har udskiftet resilience med } \\
\text { livsduelighed (Cefai, 2008). } \\
\text { Resiliens kan styrkes gennem etablering af } \\
\text { muligheder, for alle børn, i skolemiljøet - } \\
\text { særligt klasserummet. Resiliensunderstøttende } \\
\text { kontekster indeholder omsorg, meningsfuldt } \\
\text { engagement og høje forventninger. }\end{array}$ \\
\hline $\begin{array}{l}\text { Linder, 2015; Linder } \\
\text { \& Ledertoug, } 2014 \\
\text { (Bøger) }\end{array}$ & $\begin{array}{l}\text { Livsduelighed som udsprunget af } \\
\text { resiliensforskningen. }\end{array}$ & $\begin{array}{l}\text { Livsduelighed er ikke sort-hvid, men snarere } \\
\text { et bredt begreb, der beskriver grader af evnen } \\
\text { til at klare livet. }\end{array}$ \\
\hline $\begin{array}{l}\text { Holm, } 2014 \\
\text { (Artikel) }\end{array}$ & $\begin{array}{l}\text { Livsduelighed som udtryk for en } \\
\text { normativ holdning til, hvem der er } \\
\text { god-nok }\end{array}$ & $\begin{array}{l}\text { Begrebet er i sammenhæng med resiliens } \\
\text { tomt og bliver derfor udfyldt med normativt } \\
\text { indhold ud fra aktuelle diskurser. }\end{array}$ \\
\hline
\end{tabular}

\section{Resiliens}

Første bevægelse er $(n=15)$ tekster, hvor resiliens er hovedbegrebet, men stadig repræsenterer forskellige forståelser.

Roffey indleder sin artikel med en reference til hverdagens magi og hverdagens magikere (Roffey, 2017). Dette er referencer til Masten (2001), hvor Roffey skriver, at børn der oplever modstand, ikke bare hiver sig selv op ved håret: "Resiliente børn har uvægerligt været omgivet af et støttende socialt miljø på et eller andet tidspunkt i deres $\operatorname{liv}(\ldots)$ " (Roffey, 2017, s. 38). Hverdagens magikere refererer til de mange fagprofessionelle og private relationer i barnets liv. Relationer, der tilbyder støtte, opbygger positive relationelle værdier, men har samtidig høje forventninger til børnene. Læringsmiliøets sociale aspekter har stor betydning, og Roffey argumenterer for, at vi ikke altid ved, hvem der har problemer i livet. Derfor er det rationelt at lade resiliensindsatser gælde alle. Hun mener, at der bør fokuseres på en udforskning af de faktorer, som bidrager til venskab, inklusion og støtte blandt børnene.

Sørensen (2008) fokuserer primært på resiliens i daginstitutionen, men vægter dog skolen tilstrækkeligt til, at hun her inddrages. Indgangsvinklen er mønsterbrydning, hvor Sørensen beskriver den nye optik, resiliens, hvor man er interesseret i omstændighederne, der gør, at ikke alle rammes af social arv (Sørensen, 2008). Her introduceres resiliens som et relativt nyt begreb i mønsterbryderforskningen, hvor synet er: "Resiliens er ikke begrænset til barnets medfødte potentialer eller grader af biologisk robusthed; det er både i og udenfor barnet, hvor miljøet spiller en mere aktiv rolle" 
(Sørensen, 2008, s. 26). Sørensen ser resiliens som et vigtigt redskab for professionelle i den daglige omgang med børn, da resiliensfremmende faktorer i og omkring barnet kan understøtte positiv udvikling og imødekomme problemstillinger. Børn dobbeltsocialiseres i Danmark og stifter tidligt bekendtskab med institutioner, hvor de kan udvikle relationer til andre børn og fagprofessionelle. Det gør lærere og pædagoger til vitale forebyggende personer og skolen til et resiliensunderstøttende miljø. Den amerikanske resiliensforsker Bernard (2004) kalder dette en turnaround teacher, og i Sørensens tekst bærer casen titlen: Min bedste ven er min klasselcerer! (Sørensen, 2008). I Sørensens artikel diskuteres begreberne mønsterbrud samt social arv og konkluderes, at de ofte bruges til, på en generaliseret, endimensionel og deterministisk måde at argumentere for, at for de fleste er den sociale arv determinerende. Du bliver som dine forældre.

Spicker (2016) anvender en komponentforståelse af resiliens. Der tages et udpræget individualiserende afsæt i forståelsen af resiliens: "det er ikke hvad vi møder af modgang og udfordringer i livet, men hvordan vi møder dem, som har betydning for og effekt på vores mentale udvikling” (Spicker, 2016, s. 76). Citatet synes tautologisk, da der kan argumenteres for, at vores mentale udvikling bestemmer, hvordan vi møder modgang, hvilket derpå skaber den mentale udvikling. Den mentale udvikling bliver derved sin egen forklaring eller årsag. Samtidig understreges det, at man som en del af det Resiliens Trenings Program, der skrives om, skal udfylde et sociogram over elevens sociale netværk og relationer. Det er dog uklart beskrevet, hvordan dette sociogram inddrages i træningen, selvom der argumenteres for, at man bør inddrage elevens primære omsorgspersoner for at gøre træningens resultater mere bæredygtige. Der argumenteres ligeledes for, at der er sammenhæng mellem selvregulering og gode relationer (Spicker, 2016, s. 77).

Sejer Nielsen (2014) peger på skolen som en vigtig faktor i forebyggelse af uønskede konsekvenser af en risikofyldt tilværelse. Der tales om, hvorledes unge kan vende tilbage til skolen og få mulighed for at påbegynde en resiliensproces i den institutionelle ramme, som skolen udgør. Der tages udgangspunkt i et menneskes proces med et blik for resiliens som kontekstuel og dermed knyttet til en institutionel ramme.

Nielsen (2004) fremhæver, at det ikke kun er individuelle egenskaber, der understøtter resiliensprocesser, men at den findes $\mathrm{i}$ styrkende sociale relationer $\mathrm{i}$ form af tilknytning, støtte og accept og opbygning af nye alternative narrativer præget af sammenhæng. Resiliens bliver dermed også beskrevet som, at barnet får mulighed for at udvikle evner til at opsøge støtte i netværket. Hvorvidt mulighed for resiliens da primært ligger i evnen, eller i støtten i netværket, er ikke helt klart defineret, men der er alligevel et klart blik for en social dimension af resiliens. Nielsen bruger det engelske ord resilience, hvor alle andre tekster i denne oversigt benytter ordet resiliens. I Nielsens (2004) artikel argumenteres der ligeledes for skolens rolle i forhold til at give mulighed for tilknytning: "Tilknytning etableres i gensidighed både i forhold til én bestemt person (dyadisk), i forhold til familien og i forhold til det større sociale netværk og 
fællesskab, hvilket for udsatte børns vedkommende ofte vil være pædagoger, lærere og gruppen af børn i en daginstitution eller skoleklasse - samt i private og i det uformelle netværk" (Nielsen, 2004, s. 73). Nielsen beskriver, hvordan særligt lærere og pædagoger kan spille en rolle i at bygge tryg tilknytning, der fordrer, at de aktivt arbejder på at etablere socialt bæredygtige relationer til børn og unge. I tillæg til dette vil oplevelsen af at føle sig integreret i et større system som et lokalområde være støttende. Hvis der er familiemæssige udfordringer, vil de professionelle blive stærke markører og aktører i udviklingen af alternative miljøer. Miljøer præget af klare værdier vedrørende mellemmenneskelige relationer, anerkendende sprogbrug, etik og moral og respekt.

Rasmussen (2014) benytter en definition udarbejdet af Schultz Jørgensen, Sommer og Dencik (2008) til at skrive: "Resiliens betyder altså, at barnet fungerer godt, selvom det har været eller er udsat for risici. Det fungerer altså normalt, selvom omgivelserne er unormale" (Rasmussen, 2014, s. 20). Ligeledes beskrives det, at resiliens udvikler sig i samspillet mellem individuelle, medfødte egenskaber og omgivelserne. Der lægges vægt på, at beskyttelsesbegrebet ikke kan ses uafhængigt af sammenhængen. Beskyttelse $i$ én sammenhæng kan være en risiko i en anden. I Rasmussens artikel (2014), beskrives det, at en deterministisk opfattelse af social arv medvirker til at gøre oplevelsen af bestemte grupper af elever elendighedsorienteret. Hun argumenterer for en tværfaglig indsats, hvor skolesundhedsplejen gennem ressourcesyn kan bidrage til at sætte fokus på ressourcerne hos både børn og omgivelser. Hun lægger vægt på, at resiliens i praksis skaber en mulighed for at tænke i helheder og giver plads til individuelle variationer.

Leoni (2016) betoner fællesskabet som en betydningsfuld del af resiliens: "Resiliens handler om vores indre styrke og om det stærke og trygge fællesskab - det handler om at blive STÆRKE SAMMEN" (Leoni, 2016, s. 5). Der er her en social forstålse af resiliens, altså en vægtning af den sociale komponent i resiliensprocessen, hvilket især viser sig i titlen på hele projektet, nemlig Sterke Sammen, om end der stadig sprogligt set skelnes mellem indre styrke og det stærke, trygge fællesskab. Dette gentages i en rapport om samme projekt (Ladegaard, 2016). Der kan i denne beskrivelse være en tendens til at gøre resiliens og trivsel til synonymer.

Belling \& Frandsen (2017) tager udgangspunkt i et citat fra Masten: "Jeg tænker på resiliens som evnen til at tilpasse sig. Når vi ser på det enkelte menneske, ser vi manifestationen af den evne. Hvis samfundet vil ruste mennesker til at håndtere kriser, må det opbygge systemer og netværk, der hjælper mennesker til at tilpasse sig" (Masten, 2016, s. 14). Med afsæt i dette definerer Belling \& Frandsen resiliens: "som evnen til at tilpasse sig og respondere på forandringer, hvad enten de kommer udefra eller indefra, mens bæredygtighed handler om en forholden sig til selve de strukturer og mekanismer, der skaber forandringerne" (Belling \& Frandsen, 2017, s. 167). Denne definition betoner resiliens som tilpasning til forandringer. Hvilket kan læses som en omskrivning af, at resiliens handler om at udvikle sig på trods af modgang. At forholde sig til de strukturer, der skaber forandring, defineres som bæredygtighed. Begrebsmæssigt er der tale om brede begreber uden klare definitioner og med vægt på tilpasning. I dette begreb om resiliens som tilpasning findes der en klar social 
orientering, eftersom resiliens indeholder tilpasning, der logisk set må omfatte en kontekst af politisk, materiel og/eller social art. Dette bliver dog uklart ved, at forandringerne også kan komme indefra.

Jakobsen (2014) argumenterer for, at resiliens kan defineres som en proces, der er et resultat af dynamiske samspil mellem barnet og dets omgivelser (Jakobsen, 2014). Videre skriver hun, at et lighedstegn mellem robusthedsbegrebet og resiliens kommer til at reducere resiliens til en egenskab ved barnet. I en senere grundbog Pedagogen som myndighedsperson skriver hun: "Resiliensbegrebet bruges både til at beskrive den proces, hvor barnet, den unge eller den voksne kommer i trivsel igen, samt til at beskrive den kapacitet, der skal til, for at man trives godt igen" (Jakobsen, 2017, s. 232). Denne forståelse lægger op til, at resiliens kan bruges som paraplybegreb for et komplekst fænomen.

Linder (2016a, 2016b) knytter resiliensbegrebet sammen med et begreb om livsduelighed, der omfatter handlingstillid, håb og optimisme. Linder mener, begreberne modstandsdygtighed og robusthed omfatter nogle af de samme elementer, men at de mangler den positive og udviklingsmæssige twist, som livsduelighedsbegrebet rummer. Resiliens dækker da livsduelighed på-trods-af modgang. I denne kontekstualisering ses igen en åbning for resiliens som værende imellem en person og en modgang, snarere end at være en indre evne i personen. Resiliens er dermed altid relationel, hvilket dog ikke udfoldes i teksten.

Månsson (2017) beskriver, hvorledes resiliens tidligere blev opfattet som knyttet til egenskaber i det enkelte menneske, hvorfor han nu benytter betegnelsen social resiliens, da resiliens i langt højere grad er et socialt fænomen, der kan forandres over tid. I denne definition lægger han vægt på Ungars begreber forhandling og navigation (Ungar, 2012). Månsson beskriver social resiliens som en udviklingsproces, der er afhængig af samspillet mellem de sociale relationer og den enkelte (Månsson, 2017).

Dalsgaard, Elkrog Hansen, \& Skovgaard (2016) står bag rapporten Resiliensfremme $i$ Skolen, der beskriver, hvordan lærernes handlinger: "understøttede elevernes resiliensprocesser, altså elevernes muligheder for at klare sig bedre end forventet i skolen, på trods af faglige udfordringer" (Dalsgaard et al., 2016, s. 8). I rapporten ser vi, at begreberne resiliens og robusthed anvendes synonymt. Dette begrundes med at øge læsevenligheden, hvilket kan skabe et kollaps mellem de to begreber. Dalsgaard et al. (2016) argumenterer for, at robusthed mangler et element af elasticitet, som rummes af resiliens. Hvorvidt elasticiteten knytter sig til konteksten, synes ikke helt klart formuleret, men det er tydeligt formuleret, at robusthed er placeret i personen. Rapporten er et af de få steder, hvor den danske skoletradition faktisk nævnes som en måde at styrke resiliens på. De henviser til Hendersons resilienshjul (Henderson, 2012), som de bruger i deres resiliens-træningsprogram. Hjulet omfatter, at man i skolen skaber, vedligeholder og udbygger et miljø, der: 1) giver eleverne social støtte og anerkendelse, 2) lader eleverne marke, at der er sat høje mål og at der er positive forventninger til, at de kan nå disse mål, 3) der giver eleverne muligheder for at deltage $i$ for dem meningsfulde aktiviteter, 4) der hjalper eleverne med at opbygge pro-sociale vardier gennem relationer til hinanden, 5) der inviterer eleverne ind i klare rammer og dermed 
styrker laringsmiljøet, 6) der $i$ praksis viser eleverne, hvordan gode miljøer, der fremmer trivsel for alle, kan opbygges og vedligeholdes, så de kan tage denne viden med sig, når de forlader skolen (Henderson, 2012, s. 298; Forfatternes oversættelse). Dalsgaard et al. (2016) skriver, at de anser resiliens-hjulet som et anvendeligt og operationaliserbart rammeværktøj for lærerens arbejde med at fremme børn og unges resiliens i en skolekontekst. Men samtidig skriver de, at det faktisk blot beskriver det, der kendetegner almen, god lærergerning i Danmark. Dalsgaard et al. konkluderer, at lærerne i deres program allerede benyttede sig af de seks resiliensfaktorer fra resiliens-hjulet. De skriver videre, at den høje normering af lærere i forhold til antallet af deltagende børn gjorde det muligt at "støtte og drage omsorg, skabe mulighed for meningsfuld deltagelse, og øge muligheden for elevernes positive tilknytning til læringen" (Dalsgaard et al., 2016, s. 93).

\section{Robusthed}

Den anden bevægelse i tekstbeskrivelser af resiliens er begrebet robusthed. Her har vi inkluderet tekster, hvor begreberne resiliens/robusthed i udtalt grad overlapper, men har primær vægtning på robusthed $(n=4)$.

Bak (2016) giver følgende beskrivelse: "Der er grænser for robusthed, grænser som er stærkt individuelle. Man kan være født med en generel høj robusthed eller omvendt en generel sårbarhed. Robusthed påvirkes af opvækstvilkår, livsbegivenheder og aktuelle livsvilkår (Bak, 2016, s. 32). Det anerkendes således, at robusthed påvirkes af kontekst, men begrebet repræsenterer alligevel et stærkt individualiseret syn på menneskers styrke. Bak (2016) skriver, at det begreb, der hyppigst anvendes i faglitteraturen om robusthed, er resiliens, og sætter dermed lighedstegn mellem disse to begreber.

Bak \& Lima (2017) skriver direkte i en redskabsbog til professionelle og forældre: "Definitionsmæssigt er der ingen forskel på, om man bruger ordet resiliens eller ordet robusthed." (Bak \& Lima, 2017 s. 8.). Med dette begrebsmæssige kollaps bruges to begreber om det samme.

Schultz Jørgensen (2017) skelner mellem robusthed som adferd og robusthed som egenskab. Robusthed som adfærd defineres som momentan og kortvarig, mens robusthed som egenskab defineres som internaliseret i personligheden (Schultz Jørgensen, 2017, s. 15). Her ser Schultz Jørgensen det pædagogiske projekt i at udvikle robusthed som liggende mellem disse to. Jørgensen mener, at robusthed skal tjene et frigørende perspektiv (Schultz Jørgensen, 2017 s. 22). Han sidestiller modstandskraft og resiliens. I sin definition af resiliens benytter han modstandskraft, robusthed og resiliens i samme sætning. Han refererer endvidere til, at resiliens også kan forstås med dobbelthed, som konkurrencestatens nye tro veebner. ${ }^{4} \mathrm{Han}$ argumenterer for, at resiliens er en kompleks, dynamisk sammenhæng mellem noget, barnet har med sig

\footnotetext{
${ }^{4}$ Artikel i informationen, 10. september, 2016 hvor resiliens problematiseres som neoliberalt redskab
} 
i sin psykiske baggrund, og noget, der kaldes frem i samspillet med vigtige personer i opvækstmiljøet. Modstandskraft bliver dernæst defineret som en del af robusthed. Men det bliver ikke klart, hvordan de enkelte begreber defineres. Det bliver heller ikke klart, hvad der er individuelle, og hvad der er miljømæssige faktorer. Dette betyder, at det kan anskues som en komponentteori, hvor forskellige begreber siger det samme, uden klare afgrænsninger. Robusthed bliver vagt defineret som individuelt og miljømæssigt på samme tid, men uden at der gives en klar definition af helheden af disse eller dynamikken mellem dem, hvis det er komponenter, der tænkes i.

Hansen (2006) beskriver de robuste som overlevere og benytter i sin definition resiliens og robusthed sammen: "Begrebet robusthed (kommer af det latinske robus, robur: styrke) kan med fordel suppleres med det engelske ord resilience, som hentyder til spændstighed, elasticitet, livskraft, livsmod, robusthed, ukuelighed (Hansen, 2006, s. 135). Begrebsmæssigt er det uklart, hvad der menes med, at et begreb suppleres med et andet. Det er ligeledes uklart, hvad der menes med, at et begreb hentyder til en række meget forskellige andre begreber.

\section{Livsduelighed}

Den tredje bevægelse er livsduelighed. Begrebet præsenteres i teksterne som værende udsprunget af resiliensforskningen, og at det er en dansk opfindelse $(n=4)$. Begrebet repræsenteres primært af Linder, dog også af Ledertoug, i relation til den danske folkeskole. Mange teksters referencer til begrebet baseres på bogen Promoting Resilience in the Classroom: a guide to developing pupils'emotional and cognitive skills (Cefai, 2008), hvor den danske oversætter har udskiftet resilience med livsduelighed (Cefai 2009).

Linder (2015) ser begrebet livsduelighed som udsprunget af resiliensforskningen og henviser til Garmezy \& Rutter (1988) og præsenterer Zands (2014) definition. I Linder og Ledertoug (2014) beskrives livsduelighed igen som udsprunget af resiliensforskningen: "For at skabe en kobling mellem folkeskolereformen og Hatties forskning introduceres begrebet "livsduelighed", der udspringer af resiliensforskningen, der sætter fokus på, hvilke beskyttende faktorer der indvirker positivt på børns udvikling" (Linder \& Ledertoug, 2014, s. 15). De beskriver, hvordan livsduelighed ikke er sort-hvid, men snarere et bredt begreb, der beskriver grader af evnen til at klare livet.

Holm (2014) argumenterer da også for, at begrebet livsduelighed blot kan være udtryk for en normativ holdning til, hvem der er god-nok. Selve begrebet livsduelighed har et vist normativt præg og synes at blive selvbekræftende. Hvis det går godt, er man livsduelig, hvis det går skidt, er man det ikke. Begrebet fremstår i sammenhæng med resiliens tomt og bliver måske derfor udfyldt med normativt indhold ud fra aktuelle diskurser.

\section{Diskussion}

Metoden i dette studie var et litteratur review med en efterfølgende tematisk analyse. I vores analyse af teksterne var vi optaget af at forstå forskellige teksters måder 
at fortolke og forklare resiliens på $\mathrm{i}$ relation til den danske skoleverden. En måde synes at være at erstatte ordet resiliens med andre begreber såsom robusthed og livsduelighed.

Et gennemgående træk i definitionerne og beskrivelserne, som vi fandt, var, at flere forfattere anvender en såkaldt komponentteori, hvor der optræder en dualistisk orienteret opfattelse af komponenter, altså et samspil mellem noget indre og noget ydre. Denne teoretiske model er dominerende inden for definitionen af resiliens i teksterne, hvorved der sker en diskursiv naturalisering - altså at det bliver selve den teoretiske forudsætning, at der er to komponenter på spil, det indre og det ydre. Medfødt robusthed placeres i den individuelle komponent, og bevægelsen med oversættelse og anvendelsen af robusthedsbegrebet medfører, at resiliens ses som en individuel kapacitet. Det betyder, at robusthedsteorier kommer til at fremskrive en forståelse af resiliens, der lægger meget vægt på den individuelle kompetence og langt mindre vægt på miljømæssige faktorer og livsvilkår.

Bevægelsen mod livsduelighedsbegrebet synes ikke at bidrage afklarende til en dansk definitionen af resiliens, selvom det faktisk er et forsøg på at finde et dansk ord for resiliens. Endvidere er begrebet i sig selv løst defineret. Der er forskellige idealer for det normative over tid, og det er i kampen mellem disse forskellige diskurser, at livsduelighed normsættes. Denne argumentation betyder så, at livsduelighed er kontekstafhængig, nemlig ved at blive defineret ud fra bestemte, socialt cirkulerende diskurser. Der er nogen, som definerer livsduelighed og dermed hvem, der er livsduelige. Ifølge denne argumentation er livsduelighed ikke en indre evne, men en diskursiv udpegning. Dog vil forfatterne påpege, at der også i forståelsen af resiliens som det at klare sig på trods eller klare sig bedre end forventet - altid ligger en opgave i at definere, hvad dette at klare sig bedre er i den givne sammenhæng. Samt at tydeliggøre hvilke begivenheder og vilkår, der ligger til grund for, at det at klare sig er blevet udfordret.

Som nævnt kan resiliens beskrives som et vagt begreb, da det ikke er entydigt defineret. Derfor kan det forekomme nærliggende blot at erstatte resiliens med et andet ord, som om resiliens er et fremmedord, der skal oversættes. Dette kan ses som en ikke-intenderet konsekvens af resiliens som et vagt begreb. Men vi fandt også et næste skridt, som opponerer mod dette: Hvis resiliensprocesser opstår ved et stadigt samspil mellem individ og miljø, må dette logisk betyde, at individer ikke i sig selv, løsrevet fra en kontekst, kan være resiliente eller ikke-resiliente. Dalsgaard et al. (2016) præsenterer også 'educational resiliency' til at beskrive en vellykket resiliensproces i skolen: "Resiliens kan ikke (udelukkende) styrkes via viljestyrke. Som allerede anført udvikles resiliens gennem interaktionen mellem den enkelte og miljøer som familie, skole, nabolag og endnu bredere dele af samfundet" (Dalsgaard et al., 2016, s. 23) fra (Brooks, 2006, s. 70). Der er således stadig tale om en opfattelse af to komponenter, men netop med hensyn til definitionen af resiliens, sker der en tydelig bevægelse væk fra det individualiserende og over mod en kontekstuel og - dermed muligvis - social forståelse af resiliens. 
Kompleksiteten i resiliensbegrebet og de mange forskellige bud på afgrænsning (vaghed) kan betyde, at begrebet $\mathrm{i}$ en hverdagspraksis kan blive underlagt mange synsninger, det vil sige idiosynkratiske definitioner, som er private og udokumenterede. Disse synsninger kan føre til, at robusthed, livsduelighed og resiliens bliver blandet sammen, når resiliens diskuteres i forhold til børn og unge i Danmark. Den sprogbrug og de begreber, vi som professionelle benytter til at forstå vores praksis, har stor betydning for vores handlinger og dermed for særdeles mange børneliv. Det har betydning, hvilke værdier vi italesætter, og især hvilke værdier vi viser i praksis. Da resiliens er et begreb med både kompleksitet og vaghed, er det nødvendigt til stadighed at skærpe begrebet fremadrettet, så det ikke mister sin værdi for de fagprofessionelle i skolen. Amerikanske skoleforskere som Henderson (2012) og Bernard (2004) har skrevet direkte om resiliens i skolen. Her er megen god almen teori og også holdbare empiriske studier at bygge på. Forskningen er dog primært fra nordamerikanske skoler, hvorfor det er interessant fremover at følge anvendelsen af viden om resiliens i danske skoler, da disse er udviklet som en del af den skandinaviske model for velfærdsstater (Andersen et al., 2007; Esping-Andersen, 1990; Jensen \& Svendsen, 2011). Et næste skridt vil være forskningsmæssigt at følge, hvad det betyder for børns trivsel i den danske folkeskole, at vi nu også arbejder med et begreb om resiliens.

\section{Forfatteromtale}

Jeppe Kiel Christensen er ph.d-stipendiat ved Aarhus Universitet og VIA University College, hvor han forsker i community- og social resiliens, særligt i forbindelse med skoler.

Peter Berliner er professor ved Institut for Sociale Forhold, Økonomi og Journalistik ved Ilisimatusarfik/Grønlands Universitet og ved Aarhus Universitet, hvor han forsker i sociale lærings- og udviklingsprocesser med særligt henblik på helende læring i samfund.

Ida Skytte Jakobsen er docent ved Center for anvendt velfærdsforskning, UCL Erhvervsakademi og Professionshøjskole, hvor hun forsker i resiliensprocesser særligt i forbindelse med udsatte børn og unge.

\section{Referencer}

Andersen, T. M., Holmström, B., Seppo Honkapohja, S., Korkman, S., Söderström, H. T., \& Vartianinen, J. (2007). The Nordic Model - Embracing globalization and sharing risks. Helsinki: The Research Institute of the Finnish Economy (ETLA)/Taloustieto Oy.

Bak, P. L. (2016). Robusthed. In Knudsen, A., \& Jacobsen, C. (2016). De første år $i$ skolen - efter reformen (s. 30-41). København: Nota.

Bak, P. L., \& Lima, S. de. (2017). Robusthed: en redskabsbog for professionelle og forceldre (1. udgave). Aarhus: Klim.

Belling, L., \& Frandsen, L. (2017). Bcredygtig dannelse: skitser til en empatisk verden (1. udgave). Frederikshavn: Dafolo. 


\section{Feppe Kiel Christensen, Peter Berliner og Ida Skytte Fakobsen}

Bernard, B. (2004). Resiliency: what we have learned. San Francisco, Calif: WestEd.

Brooks, J. E. (2006). Strengthening Resilience in Children and Youths: Maximizing Opportunities through the Schools. Children \& Schools, 28(2), 69-76.

Cefai, C. (2008). Promoting resilience in the classroom: a guide to developing pupils' emotional and cognitive skills. London: Jessica Kingsley Publishers.

Cefai, C. (2009). Frem elevens livsduelighed. Virum: Dansk Psykologisk Forlag.

Dalsgaard, J., Elkrog Hansen, L. M., \& Skovgaard, T. (2016). Resiliensfremme $i$ skolen: følgeforskning $i$ indsatsen talent, potentiale og social mobilitet 2015-2017. Odense: Forsknings- og Innovationscenter for Idræt, Bevægelse og Læring.

Esping-Andersen, G. (1990). The three worlds of welfare capitalism. Oxford: Polity Press.

Garmezy, N., \& Rutter, M. (1988). Stress, coping, and development in children. A fohns Hopkins paperback (Johns Hopkin). Baltimore, Md.: Johns Hopkins University Press.

Hansen, A. D. (2006). Lærerens robusthed og sårbarhed - en dimension i skole-hjem samarbejdet. In Skole og hjem samarbejdet: en håndsrcekning til lcereruddannelsen. København: Unge Pædagoger.

Hart, A., Blincow, D., \& Thomas, H. (2007). Resilient therapy: working with children and families. East Sussex UK: Routledge.

Henderson, N. (2012). Resilience in Schools and Curriculum Design. In M. Ungar (Ed.), The Social Ecology of Resilience: A Handbook of Theory and Practice (s. 297-306). New York, NY: Springer New York.

Holm, C. (2014). Paradigmeskift mod en ny livsduelig pædagogik. Pcedagogisk Psykologisk Tidsskrift, 51(4), 62-76.

Jakobsen, I. S. (2014). Resiliensprocesser: begreb, forskning og praksis (1. udgave). København: Akademisk Forlag.

Jakobsen, I. S. (2017). Forebyggelse ud fra et resiliensperspektiv. In Pcedagogen som myndighedsperson: en grundbog, (s. 231-251). Forlaget: Samfundslitteratur

Jensen, C., \& Svendsen, G. T. (2011). Giving money to strangers: European welfare states and social trust. International fournal of Social Welfare, 20(1), 3-9.

Ladegaard, L. (2016). "Man kan jo ikke sige det til de voksne, hvis man ikke ved, at det er forkert": en dokumentation af tilgange, processer, best practices og erfaringer med projektet "Børns beredskab mod vold og overgreb" om børns rettigheder, resiliens, handlemuligheder og dermed trivsel og lering $i$ de danske skoler. København: Red Barnet.

Leadbeater, B., Dodgen, D., \& Solarz, A. (2005). The Resilience Revolution. In R. D. Peters, B. Leadbeater, \& R. J. McMahon (Eds.), Resilience in Children, Families, and Communities: Linking Context to Practice and Policy (s. 47-61). Boston: MA: Springer US.

Leoni, S. J. (2016). Stcerke sammen: et lcringsforløb til mellemtrinnet, der styrker klassefcellesskabet og det enkelte barn. København: Red Barnet.

Linder, A. (2015). Livsduelighedens pædagogik: faglige pointer til den relationsprofessionelle. Relationsprofessionsserien. Frederikshavn: Dafolo.

Linder, A. (2016a). Livsduelighed og børns nysgerrighed. In R. Kristensen \& T. Szulevicz (Eds.), Understøttende undervisning og lceringsmiljøer (s. 157-169). Frederikshavn: Dafolo

Linder, A. (2016b). Professionel relationskompetence: stjernestunder $i$ det relationelle univers. Frederikshavn: Dafolo.

Linder, A., \& Ledertoug, M. M. (2014). Livsduelighed og børns karakterstyrker (1. udgave). København: Dansk Psykologisk Forlag.

Lipsitt, L. P., \& Demick, J. (2012). Theory and Measurement of Resilience: Views from Development. In M. Ungar (Ed.), The Social Ecology of Resilience: A Handbook of Theory and Practice (s. 43-52). New York, NY: Springer New York.

Månsson, H. (2017). Udvikling af social resiliens i skolen. Kognition E⿱ pcedagogik, Årg. 27, (72-82).

Masten, A. S. (2001). Ordinary magic: Resilience processes in development. American Psychologist, 56(3), (227-238).

Masten, A. S. (2014). Ordinary Magic: Resilience in Development. New York: Guilford Publications.

Masten, A. S. (2016). Tætte relationer fremmer resiliens hos flygtningebørn. Asterisk, 77, 14-15.

Nielsen, J. (2004). Problemadferd: børns og unges udfordringer til fellesskabet. København: Hans Reitzel.

Prince-Embury, S., \& Saklofske, D. H. (2013). Resilience in children, adolescents, and adults: translating research into practice. The Springer series on human exceptionality. New York: Springer Science+Business Media.

Rasmussen, S. (2014). Resiliensorienteret arbejde i skolesundhedsplejen. Sundhedsplejersken, 2014(4), $20-22$.

Roffey, S. (2017). "Hverdagens magi" kræver magikere i hverdagen: positive relationers betydning og praksis $i$ opbygningen af resiliens og trivsel hos børn og unge. Kognition E pæedagogik, Arg. 27, nr 103, 38-57.

Schultz Jørgensen, P. (2017). Robuste børn: giv dit barn ansvar, livsmod og tiltro til sig selv (1. udgave). København: Kristeligt Dagblad. 


\section{Resiliensforståelser $i$ skoleverdenen}

Schultz Jørgensen, P., Sommer, D. B., \& Dencik, L. (2008). Familie og børn i en opbrudstid (1. udgave). København: Hans Reitzel.

Sejer Nielsen, A. (2014). Det tværprofessionelle samarbejdes betydning for unges resiliensproces. Sundhedsplejersken, 2014(4), 16-19.

Sommer, D. (2017). Udvikling: fra udviklingspsykologi til udviklingsvidenskab. Professionernes begreber (1. udgave). Frederiksberg: Samfundslitteratur.

Sørensen, J. B. (2008). Støt mestring - bryd mønstre (3. udgave). København: Dansk Marte Meo Center.

Spicker, L. (2016). Hvordan kan der skabes motivation og trivsel hos udatte unge gennem træning af resiliens. Pcedagogisk Psykologisk Tidsskrift, 53(3), 75-84.

Ungar, M. (2012). The social ecology of resilience: a handbook of theory and practice. New York: Springer.

Zand, F. (2014). Resiliens: en ny tilgang. In S. Nørby \& A. Myszak (Red.) Positiv psykologi: en introduktion til videnskaben om velvare og optimale processer (s. 281-306). København: Hans Reizels Forlag.

Zautra, A. J., Hall, J. S., \& Murray, K. E. (2010). Resilience: A new definition of health for people and communities. In J. S. H. John, W. Reich, A. J. Zautra (Ed.), Handbook of adult resilience (s. 3-29). New York: Guilford Press. 